\title{
Evidence of two lineages of the symbiont 'Candidatus Erwinia dacicola' in Italian populations of Bactrocera oleae (Rossi) based on 16S rRNA gene sequences
}

Correspondence
Vincenzo Girolami
vincenzo.girolami@unipd.it

\section{INTRODUCTION}

The microbiota associated with Tephritid flies (Diptera, Tephritidae) has been the subject of many studies (Behar et al., 2009). In particular, the association between the olive fly Bactrocera oleae, the most important olive crop pest, and its symbiotic bacteria has been explored for over a century. The presence of bacterial masses inside an intestinal diverticulum located in the fly head, called the oesophageal bulb, and the intestinal lumen of the midgut of B. oleae was described for the first time by Petri (1909), based on microscopic observations. The nature of this unculturable and host-specific bacterium was investigated

\footnotetext{
Abbreviation: AMOVA, analysis of molecular variance.

The GenBank/EMBL/DDBJ accession numbers for the $16 \mathrm{~S}$ rRNA and 23S rRNA gene sequences of 'Candidatus Erwinia dacicola' are HQ667588 to HQ667589 and HQ667590, respectively. Those for the NADH1-tRNA-16S gene sequence of Bactrocera oleae are H0667572 to HQ667587, respectively.
}

in a previous study (Capuzzo et al., 2005), using molecular techniques and microbiologically controlled conditions. The bacterium was described as a novel taxon within the family Enterobacteriaceae as 'Candidatus Erwinia dacicola'. The olive fly symbiont is considered to be the most common and widespread bacterium within the olive fly population (Ben-Yosef et al., 2010); it has been found in Italy, where it was first described (Capuzzo et al., 2005; Sacchetti et al., 2008), in Spain (Silva et al., 2008), in the south-western USA (Estes et al., 2009) and in Greece (Kounatidis et al., 2009).

The last afore-mentioned study did not detect ' $\mathrm{Ca}$. E. dacicola' in their laboratory strains and found that the culturable bacterium Acetobacter tropicalis was predominant. The literature reports that symbiont losses are a consequence of rearing larvae on artificial media (Girolami \& Cavalloro, 1972; Capuzzo et al., 2005), as well as their substitution by acidophilus bacteria (Hagen, 1966). 
Table 1. Collection sites of the B. oleae populations, $16 \mathrm{~S}$ rRNA haplotype frequencies of 'Ca. E. dacicola' (htA and htB) and geographical distribution of the 16 . oleae mitochondrial haplotypes

\begin{tabular}{|c|c|c|c|c|c|c|c|c|c|c|c|c|c|c|c|c|c|c|c|c|c|}
\hline \multirow[t]{2}{*}{ Location } & \multirow[t]{2}{*}{ Coordinates } & \multirow[t]{2}{*}{$\begin{array}{c}\text { Date of } \\
\text { collection }\end{array}$} & \multirow[t]{2}{*}{$\begin{array}{l}\text { Sample } \\
\text { size }^{\star}\end{array}$} & \multicolumn{2}{|c|}{$\begin{array}{l}\text { 'Ca. E. dacicola' } \\
\text { haplotypes }\end{array}$} & \multicolumn{16}{|c|}{ B. oleae haplotypes $\dagger$} \\
\hline & & & & htA & htB & h1 & h2 & h3 & h4 & h5 & h6 & h7 & h8 & h9 & h10 & h11 & h12 & h13 & h14 & h15 & h16 \\
\hline $\begin{array}{l}\text { 1. Campione } \\
\text { (Lombardy) }\end{array}$ & $\begin{array}{c}45^{\circ} 58^{\prime} \mathrm{N} \\
08^{\circ} 58^{\prime} \mathrm{E}\end{array}$ & $10 / 2009$ & 8 & 3 & 5 & & & & & & & & & & & & & & & & \\
\hline $\begin{array}{l}\text { 2. Bardolino } \\
\text { (Veneto) }\end{array}$ & $\begin{array}{c}45^{\circ} 32^{\prime} \mathrm{N} \\
10^{\circ} 43^{\prime} \mathrm{E}\end{array}$ & $12 / 2008$ & 8 & 5 & 3 & & & & & & & & & & & & & & & & \\
\hline 3. Dueville (Veneto) & $\begin{array}{l}45^{\circ} 38^{\prime} \mathrm{N} \\
11^{\circ} 32^{\prime} \mathrm{E}\end{array}$ & $10 / 2009$ & 14 & 3 & 11 & & & & & & & & & & & & & & & & \\
\hline $\begin{array}{l}\text { 4. Marostica } \\
\text { (Veneto) }\end{array}$ & $\begin{array}{l}45^{\circ} 44^{\prime} \mathrm{N} \\
11^{\circ} 39^{\prime} \mathrm{E}\end{array}$ & $10 / 2007$ & $13(10)$ & 0 & 13 & $4_{\mathrm{B}}$ & $3_{\mathrm{B}}$ & $22_{\mathrm{B}}$ & & & & & & & & & & & $1_{\mathrm{B}}$ & & \\
\hline \multirow[t]{3}{*}{$\begin{array}{l}\text { 5. Montegrotto } \\
\text { Terme (Veneto) }\end{array}$} & $\begin{array}{l}45^{\circ} 19^{\prime} \mathrm{N} \\
11^{\circ} 47^{\prime} \mathrm{E}\end{array}$ & $12 / 2007$ & $15(5)$ & 4 & 11 & $22_{\mathrm{B}}$ & $1_{\mathrm{B}}$ & & $1_{\mathrm{B}}$ & & & & & & & & & & & $1_{\mathrm{B}}$ & \\
\hline & & $11 / 2008$ & 8 & 4 & 4 & & & & & & & & & & & & & & & & \\
\hline & & $12 / 2009$ & 17 & 5 & 12 & & & & & & & & & & & & & & & & \\
\hline \multirow[t]{3}{*}{$\begin{array}{l}\text { 6. Diano Marina } \\
\text { (Liguria) }\end{array}$} & $\begin{aligned} 43^{\circ} 54^{\prime} \mathrm{N} \\
8^{\circ} 04^{\prime} \mathrm{E}\end{aligned}$ & $11 / 2006$ & 8 & 6 & 2 & & & & & & & & & & & & & & & & \\
\hline & & 09/2007 & $12(4)$ & 11 & 1 & $1_{\mathrm{B}} ; 1_{\mathrm{A}}$ & $1_{\mathrm{A}}$ & $1_{\mathrm{A}}$ & & & & & & & & & & & & & \\
\hline & & 09/2008 & $18(6)$ & 16 & 2 & $4_{\mathrm{A}}$ & & & & & & & $1_{\mathrm{A}}$ & & & & & & & & $1_{\mathrm{A}}$ \\
\hline 7. Firenze (Tuscany) & $\begin{array}{r}43^{\circ} 46^{\prime} \mathrm{N} \\
11^{\circ} 15^{\prime} \mathrm{E}\end{array}$ & $12 / 2007$ & 4 & 3 & 1 & & & & & & & & & & & & & & & & \\
\hline $\begin{array}{l}\text { 8. Capoliveri } \\
\text { (Tuscany) }\end{array}$ & $\begin{array}{l}42^{\circ} 44^{\prime} \mathrm{N} \\
10^{\circ} 22^{\prime} \mathrm{E}\end{array}$ & 08/2009 & $9(5)$ & 5 & 4 & $1_{\mathrm{B}} ; 2_{\mathrm{A}}$ & & $1_{\mathrm{B}}$ & & & & $1_{\mathrm{B}}$ & & & & & & & & & \\
\hline 9. Arezzo (Tuscany) & $\begin{array}{l}43^{\circ} 28^{\prime} \mathrm{N} \\
11^{\circ} 51^{\prime} \mathrm{E}\end{array}$ & $11 / 2009$ & 10 & 6 & 4 & & & & & & & & & & & & & & & & \\
\hline 10. Roma (Lazio) & $\begin{array}{l}41^{\circ} 53^{\prime} \mathrm{N} \\
12^{\circ} 29^{\prime} \mathrm{E}\end{array}$ & $12 / 2009$ & $12(5)$ & 2 & 10 & $1_{\mathrm{A}} ; 3_{\mathrm{B}}$ & $1_{\mathrm{B}}$ & & & & & & & & & & & & & & \\
\hline $\begin{array}{l}\text { 11. Ancona } \\
\text { (Marche) }\end{array}$ & $\begin{array}{r}43^{\circ} 37^{\prime} \mathrm{N} \\
13^{\circ} 31^{\prime} \mathrm{E}\end{array}$ & 09/2009 & $16(5)$ & 3 & 13 & $2 \mathrm{~B}$ & $3_{\mathrm{B}}$ & & & & & & & & & & & & & & \\
\hline $\begin{array}{l}\text { 12. Moscufo } \\
\text { (Abruzzo) }\end{array}$ & $\begin{array}{l}42^{\circ} 25^{\prime} \mathrm{N} \\
14^{\circ} 03^{\prime} \mathrm{E}\end{array}$ & $11 / 2009$ & 11 & 5 & 6 & & & & & & & & & & & & & & & & \\
\hline $\begin{array}{l}\text { 13. Capua } \\
\text { (Campania) }\end{array}$ & $\begin{array}{r}41^{\circ} 06^{\prime} \mathrm{N} \\
14^{\circ} 13^{\prime} \mathrm{E}\end{array}$ & 09/2009 & 10 & 1 & 9 & & & & & & & & & & & & & & & & \\
\hline $\begin{array}{l}\text { 14. Portici } \\
\text { (Campania) }\end{array}$ & $\begin{array}{l}40^{\circ} 48^{\prime} \mathrm{N} \\
14^{\circ} 20^{\prime} \mathrm{E}\end{array}$ & 09/2009 & $15(5)$ & 4 & 11 & $1_{\mathrm{B}}$ & & & $22_{\mathrm{B}}$ & & & $1_{\mathrm{B}}$ & & & & & & & & $1_{\mathrm{B}}$ & \\
\hline $\begin{array}{l}\text { 15. Rossano Calabro } \\
\text { (Calabria) }\end{array}$ & $\begin{array}{r}39^{\circ} 34^{\prime} \mathrm{N} \\
16^{\circ} 38^{\prime} \mathrm{E}\end{array}$ & 09/2009 & $9(4)$ & 2 & 7 & $22_{\mathrm{B}}$ & $1_{\mathrm{A}} ; 1_{\mathrm{B}}$ & & & & & & & & & & & & & & \\
\hline 16. Rende (Calabria) & $\begin{array}{l}39^{\circ} 19^{\prime} \mathrm{N} \\
16^{\circ} 10^{\prime} \mathrm{E}\end{array}$ & $10 / 2009$ & 7 & 2 & 5 & & & & & & & & & & & & & & & & \\
\hline
\end{tabular}


Table 1. cont.

\begin{tabular}{|c|c|c|c|c|c|c|c|c|c|c|c|c|c|c|c|c|c|c|c|c|c|}
\hline \multirow[t]{2}{*}{ Location } & \multirow[t]{2}{*}{ Coordinates } & \multirow[t]{2}{*}{$\begin{array}{c}\text { Date of } \\
\text { collection }\end{array}$} & \multirow[t]{2}{*}{$\begin{array}{c}\text { Sample } \\
\text { size }^{\star}\end{array}$} & \multicolumn{2}{|c|}{$\begin{array}{c}\text { 'Ca. E. dacicola' } \\
\text { haplotypes }\end{array}$} & \multicolumn{16}{|c|}{ B. oleae haplotypes $\dagger$} \\
\hline & & & & htA & htB & h1 & h2 & h3 & h4 & h5 & h6 & h7 & h8 & h9 & h10 & h11 & h12 & h13 & h14 & h15 & h16 \\
\hline 18. Bari (Apulia) & $\begin{array}{c}41^{\circ} 07^{\prime} \mathrm{N} \\
16^{\circ} 51^{\prime} \mathrm{E}\end{array}$ & $11 / 2002$ & 9 & 1 & 8 & & & & & & & & & & & & & & & & \\
\hline $\begin{array}{l}\text { 19. Castellana Grotte } \\
\text { (Apulia) }\end{array}$ & $\begin{array}{c}40^{\circ} 53^{\prime} \mathrm{N} \\
17^{\circ} 09^{\prime} \mathrm{E}\end{array}$ & $10 / 2009$ & 9 & 5 & 4 & & & & & & & & & & & & & & & & \\
\hline 21. Messina (Sicily) & $\begin{array}{l}38^{\circ} 11^{\prime} \mathrm{N} \\
15^{\circ} 33^{\prime} \mathrm{E}\end{array}$ & 08/2007 & $6(5)$ & 0 & 6 & & & $22_{\mathrm{B}}$ & $1_{\mathrm{B}}$ & $22_{\mathrm{B}}$ & & & & & & & & & & & \\
\hline 22. Siracusa (Sicily) & $\begin{array}{c}37^{\circ} 03^{\prime} \mathrm{N} \\
15^{\circ} 17^{\prime} \mathrm{E}\end{array}$ & $11 / 2008$ & 5 & 0 & 5 & & & & & & & & & & & & & & & & \\
\hline 23. Marsala (Sicily) & $\begin{array}{c}37^{\circ} 47^{\prime} \mathrm{N} \\
12^{\circ} 26^{\prime} \mathrm{E}\end{array}$ & 07/2008 & $15(4)$ & 0 & 15 & $2 \mathrm{~B}_{\mathrm{B}}$ & $1_{\mathrm{B}}$ & $1_{\mathrm{B}}$ & & & & & & & & & & & & & \\
\hline $\begin{array}{l}\text { 24. Bancali } \\
\text { (Sardinia) }\end{array}$ & $\begin{array}{r}40^{\circ} 44^{\prime} \mathrm{N} \\
8^{\circ} 27^{\prime} \mathrm{E}\end{array}$ & $12 / 2009$ & $5(3)$ & 5 & 0 & $2_{\mathrm{A}}$ & & & & & & & & & & $1_{\mathrm{A}}$ & & & & & \\
\hline Total & & & $311(80)$ & 134 & 177 & $15_{\mathrm{A}} ; 19_{\mathrm{B}}$ & $6_{\mathrm{A}} ; 11_{\mathrm{B}}$ & $1_{\mathrm{A}} ; 6_{\mathrm{B}}$ & $4_{\mathrm{B}}$ & $1_{\mathrm{A}} ; 2_{\mathrm{B}}$ & $2_{\mathrm{A}}$ & $2_{\mathrm{B}}$ & $2_{\mathrm{A}}$ & $1_{\mathrm{A}}$ & $1_{\mathrm{A}}$ & $1_{\mathrm{A}}$ & $1_{\mathrm{A}}$ & $1_{\mathrm{B}}$ & $1_{\mathrm{B}}$ & $2_{\mathrm{B}}$ & $1_{\mathrm{A}}$ \\
\hline
\end{tabular}

${ }^{*}$ Numbers in parentheses indicate the number of olive flies for which the mitochondrial region was sequenced.

$\dagger \mathrm{A}$ and $\mathrm{B}$ indicate symbiont haplotype. 
Olive fly larvae feed upon the pulp of fruits of the genus Olea, both wild (oleaster) and domesticated forms (Tzanakakis, 2006). Botanically, the oleaster and the cultivated form of the olive tree correspond, respectively, to Olea europaea subsp. europaea var. sylvestris and Olea europaea subsp. europaea var. europaea (Breton et al., 2006).

At present, the olive fly is found in East and South Africa, the Mediterranean basin and Pakistan (Tzanakakis, 2006). Recently, the fly has been accidentally introduced into California, USA (Rice, 1999). In Italy, as in other Mediterranean countries where the pest is recorded, the range of the olive fly traditionally matches with that of the olive tree, including both the oleaster and cultivated forms.

On the basis of these statements, the distribution of the olive fly in Italy can be divided according to: a) areas where olive trees are grown extensively and the presence of oleaster is diffused (these areas overlap with historic olive cultivating regions and with the Italian phytoclimatic subzone of warm Lauretum according to Pavari, 1916); and b) areas where olive trees are marginally cultivated and oleaster is absent. It is well-known that in the former of these two zones, populations of $B$. oleae breed all-year round and also exploit residual fruits that are present on wild olive trees during spring time (Blando \& Mineo, 2006).
To date, the genetic diversity present within the olive fly symbiont has not been investigated. In this study, the $16 \mathrm{~S}$ rRNA gene sequence diversity of the olive fly symbiont ' $\mathrm{Ca}$. E. dacicola' was examined by focusing on Italian olive fly populations. The study had the following objectives: (i) to verify the $16 \mathrm{~S}$ rRNA gene sequence diversity of ' $\mathrm{Ca}$. E. dacicola' from across Italian territory and (ii) to assess possible correlations between the genetic variability of ' $\mathrm{Ca}$. E. dacicola' and the mitochondrial haplotypes of the host fly.

\section{METHODS}

Olive fly sampling. Infested olives were collected from 26 different locations throughout Italy from 2002 to 2009 in areas where olive trees were regularly cultivated. The sampling sites were chosen in order to represent wild olive tree areas according to Pavari (1916) and Carrión et al. (2010) (Liguria coast, south Italy, Sardinia and Sicily, locations 6 and 13 to 26) and areas where olive cultivation was introduced and spread historically through human activities and where the wild olive (oleaster) was absent (North and Central Italy, locations 1 to 5 and 7 to 12) (Table 1 and Fig. 1). In addition, two populations from both areas were collected over three consecutive years and during the same season in order to detect possible variations in the distribution of different ' $\mathrm{Ca}$. E. dacicola' haplotypes over time (location 5, from 2007 to 2009 and location 6, from 2006 to 2008) (Table 1).

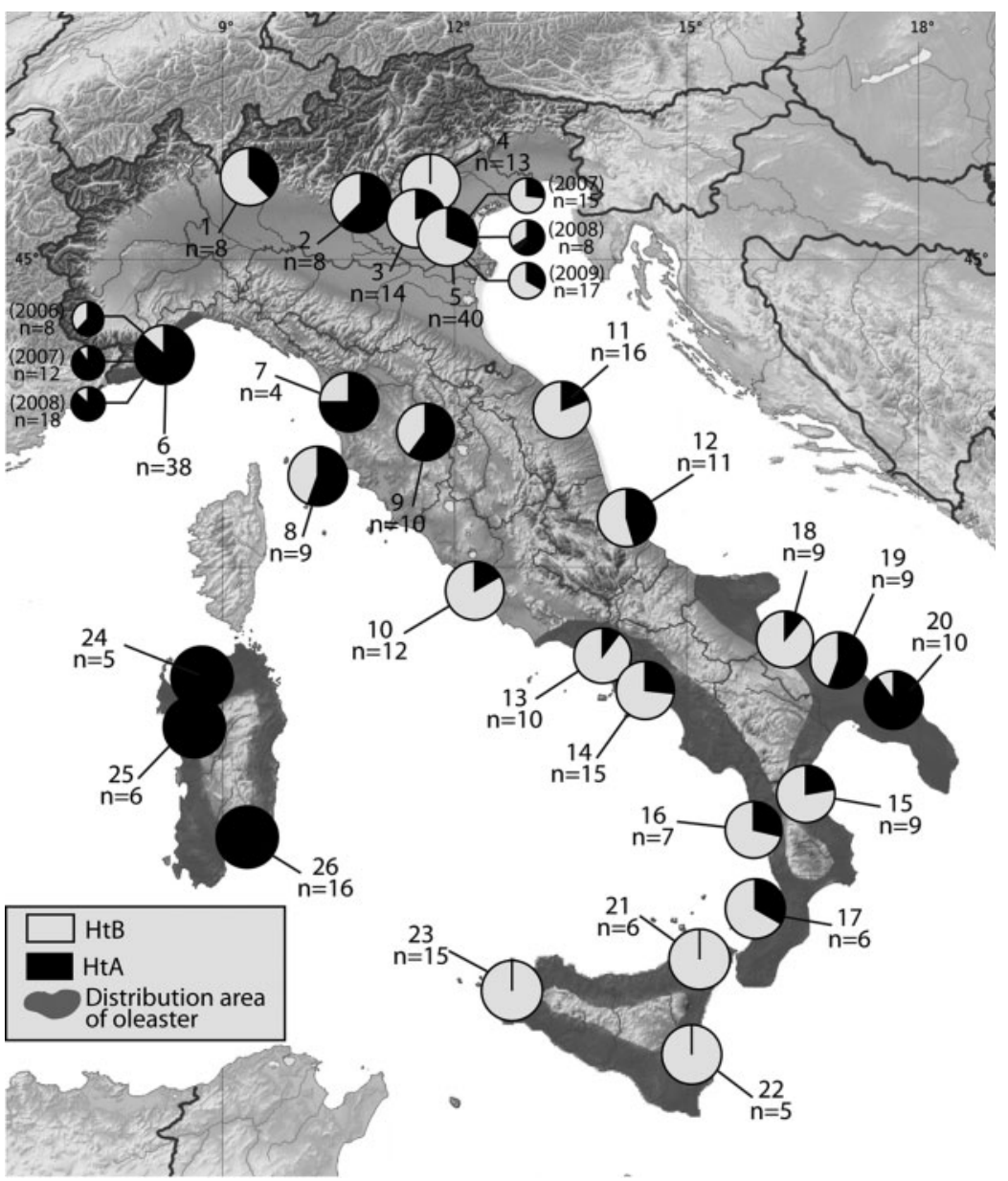

Fig. 1. Geographical distribution and proportion of the two 'Ca. E. dacicola' haplotypes among the $26 \mathrm{~B}$. oleae populations sampled in Italy. The first number indicates the location code, reported in Table 1; $\mathrm{n}$, sample size. For locations 5 and 6 , the three different years of sampling are reported in detail. The distribution area of oleaster is from Carrión et al. (2010). 
The olives were kept in transparent plastic boxes $(20 \times 15 \times 8 \mathrm{~cm})$ topped with a net until the adult flies emerged. Insects were then transferred into net rearing cages $(10 \times 10 \times 10 \mathrm{~cm})$ and fed with a sugar diet $(50 \% \mathrm{w} / \mathrm{v}$ glucose solution) and water ad libitum.

Insect dissection and symbiont analysis. In newly emerged adults, the presence of endosymbionts is sometimes too low to be detected (Girolami, 1973; Estes et al., 2009) and so only 2-3 day-old flies were processed. This ensured that a sufficient number of bacteria was present in the oesophageal bulbs.

Flies were dissected aseptically (Capuzzo et al., 2005) under a laminar flow hood in physiological saline solution $[0.9 \% \mathrm{NaCl}(\mathrm{w} / \mathrm{v})]$ under a stereomicroscope, extracting the oesophageal bulbs. Dissecting tools (forceps and tweezers) were sterilized before processing each individual insect. Oesophageal bulbs were gently transferred into Eppendorf tubes and kept at $-20{ }^{\circ} \mathrm{C}$ until further processing.

A protocol originally developed for actinomycetes was used (Palmano et al., 2000) to extract the microbial DNA content of the insect oesophageal bulbs. The bacterial $16 \mathrm{~S}$ rRNA gene was partially amplified by PCR using two pairs of universal bacterial primers: $\mathrm{fd} 1$ and $\mathrm{rp} 1$ (Weisburg et al., 1991) or 63f and 1389r (Osborn et al., 2000). The reaction mixture contained, in a total volume of $20 \mu \mathrm{l}, 1 \times$ PCR GoTaq Flexi Buffer (Promega), $2.5 \mathrm{mM} \mathrm{MgCl}_{2}, 0.1 \mathrm{mM}$ dNTPs, $0.5 \mu \mathrm{M}$ each primer, $1 \mathrm{U}$ GoTaq Flexi DNA polymerase (Promega) and a $1 \mu \mathrm{l}$ sample of a 1:30 dilution of the DNA extract. All reaction mixtures were prepared at $4{ }^{\circ} \mathrm{C}$ in $0.2 \mathrm{ml}$ reaction tubes to avoid non-specific priming. The standard thermal profile for the amplification of the $16 \mathrm{~S}$ rRNA genes was as follows: initial denaturation at $95{ }^{\circ} \mathrm{C}, 2 \mathrm{~min} ; 27$ cycles of: denaturation at $95{ }^{\circ} \mathrm{C} 30 \mathrm{~s}$; annealing at $56{ }^{\circ} \mathrm{C} 30 \mathrm{~s}$ and extension at $72{ }^{\circ} \mathrm{C} 90 \mathrm{~s}$; final extension at $72{ }^{\circ} \mathrm{C}, 5 \mathrm{~min}$.

The 23S rRNA gene region was also tested for some samples using the universal primer pair $1623 \mathrm{f}$ and 2490r (Hunt et al., 2006) under the following conditions: initial denaturation at $94{ }^{\circ} \mathrm{C}, 3 \mathrm{~min}, 30$ cycles of: denaturation at $94{ }^{\circ} \mathrm{C} 60 \mathrm{~s}$, annealing at $51{ }^{\circ} \mathrm{C}$ 60s and extension at $72{ }^{\circ} \mathrm{C} 90 \mathrm{~s}$; final extension at $72{ }^{\circ} \mathrm{C}, 5 \mathrm{~min}$.

PCR products were checked by running them on a $1.0 \%$ agarose gel stained with SYBR Safe (Invitrogen) and purified with the ExoSAP-IT kit (Amersham Biosciences) before sequencing.

The contents of eight oesophageal bulbs after PCR was cloned into JM109 competent cells using the P-GEM-T Easy vector (Promega), following the manufacturer's recommendations. Transformation was verified using PCR assays with the M13-T7 universal primer pair.

Insect host analysis. A portion of the mitochondrial DNA of the olive fly corresponding to part of the NADH dehydrogenase subunit 1 , the leucine tRNA and the $16 \mathrm{~S}$ mitochondrial region, was amplified and sequenced using the universal primer pair N1-J12261m and LRN13398 (Simon et al., 1994, 2006). This analysis was performed on the same flies in which the contents of the oesophageal bulbs were sequenced. A total of 15 olive fly populations out of 26 , representative of the main Italian regions, was processed for this task. Amplifications were performed in $20 \mu \mathrm{l}$ reaction volumes [ $1 \times \mathrm{PCR}$ GoTaq Flexi buffer (Promega), $2.5 \mathrm{mM} \mathrm{MgCl}_{2}, 0.1 \mathrm{mM}$ dNTPS, $0.2 \mu \mathrm{M}$ each primer, $0.5 \mathrm{U}$ of Taq polymerase (Promega), $2 \mu \mathrm{l}$ template DNA]. Thermal cycling conditions were $5 \mathrm{~min}$ at $96{ }^{\circ} \mathrm{C}$ followed by 35 cycles of $96{ }^{\circ} \mathrm{C}$ for $50 \mathrm{~s}, 56{ }^{\circ} \mathrm{C}$ for $50 \mathrm{~s}$ and $72{ }^{\circ} \mathrm{C}$ for $2 \mathrm{~min}$, with a final extension step of $72{ }^{\circ} \mathrm{C}$ for $5 \mathrm{~min}$.

Sequencing and data analysis. Sequencing was performed at the BMR Genomics service (Padova, Italy) on automated DNA sequencers employing the primers used for PCR amplification and, in the case of ' $\mathrm{Ca}$. E. dacicola', two additional primers for the $16 \mathrm{~S}$ rRNA gene: fL2 (Capuzzo et al., 2005) and fL4 (Mazzon et al., 2008).
Sequences were edited and aligned using MEGA 4.0.2 (Tamura et al., 2007) and chromatograms were visually inspected. A BLASTN GenBank analysis of the sequences obtained was run through the NCBI website (www.ncbi.nlm.nih.gov) to assess the identity of the sequences obtained. The Arlequin Version 3.1 software package (Excoffier et al., 2007) was used to perform the following genetic analyses on the olive fly symbiont: (i) analysis of population differentiation was accomplished by conducting exact tests of population differentiation with 100000 steps in Markov chain, with 10000 dememorization steps. (ii) An analysis of molecular variance (AMOVA) was performed to define the partition of genetic variability among populations and among groups of populations. (iii) The correlation between geographical and genetic distances ( $\mathrm{F}_{\mathrm{ST}}$ values) among populations was assessed by the nonparametric Mantel test using 1000 permutations. For this analysis, the pairwise $\mathrm{F}_{\mathrm{ST}}$ values were transformed as $\log \left[\mathrm{F}_{\mathrm{ST}} /\left(1-\mathrm{F}_{\mathrm{ST}}\right)\right]$ (Rousset, 1997).

A nested clade phylogeographic analysis (NCPA) was implemented by the ANeCa ver. 1.2 program package (Panchal, 2007), which included TCS 1.21 (Clement et al., 2000) and GeoDis 2.5 (Posada et al., 2000). The haplotype network for the mitochondrial olive fly region was constructed using the statistical parsimony algorithm (Templeton et al., 1992) which output the $95 \%$ plausible set of most parsimonious linkages among haplotypes. The NCPA first tests the null hypotheses of no association between geography and the haplotype network. Only when this null hypothesis is rejected at the $5 \%$ level of significance is it possible to infer likely historical and geographical events (Templeton et al., 1995). Fisher's exact test was applied to observe associations between the haplotype of ' $\mathrm{Ca}$. E. dacicola' and the haplotype of the insect host.

\section{RESULTS AND DISCUSSION}

\section{'Ca. Erwinia dacicola’ diversity}

A total of 314 olive fly oesophageal bulbs from 26 Italian populations were analysed with an average of 11.5 individuals per population. A GenBank similarity search (BLASTN) showed that the $781 \mathrm{bp} 16 \mathrm{~S}$ rRNA gene fragment matched with $16 \mathrm{~S}$ rRNA gene of ' $\mathrm{Ca}$. E. dacicola'. Other bacteria were predominant in only three olive flies (data not shown). When aligned by MEGA, ' $\mathrm{Ca}$. E. dacicola' sequences showed the presence of three associated point mutations. Two ' $\mathrm{Ca}$. E. dacicola' haplotypes were thus identified, hereafter referred to as haplotype A (htA) and haplotype B (htB). Sequences were deposited under GenBank accession nos HQ667588 and HQ667589, respectively. In particular, three transitions were identified. At positions 11 and 282, htA showed a $\mathrm{C}$ and htB showed a T. At position 657, htA showed a $\mathrm{G}$ and htB showed an $\mathrm{A}$. In total, htA was present in $43 \%$ of samples $(134 / 311)$ and htB was present in the remaining $57 \%(177 / 311)$.

Moreover, the 16S rRNA gene sequences of 43 ' $\mathrm{Ca}$. E. dacicola' samples derived from nine localities, 21 of which belonged to htA and 22 to htB, were extended in the $3^{\prime}$ direction up to $1280 \mathrm{bp}$ using the fL2 primer. Two further mutations were identified: at position 943 , htA showed a C and htB showed an A, and at position $945 \mathrm{bp}$, htA showed a $\mathrm{T}$ and $\mathrm{htB}$ showed an $\mathrm{A}$.

The presence of these point mutations allowed a restriction enzyme (ApaI) to be used in order to distinguish the two 
different bacterial haplotypes more quickly and with good accuracy. The digestion technique was used in addition to standard sequencing.

To date, ten sequences attributed to the ' $\mathrm{Ca}$. E. dacicola' $16 \mathrm{~S}$ rRNA gene have been deposited in GenBank (five from the USA; four from Spain and one from Italy). Eight of these sequences provided full-length coverage with the sequences of our two haplotypes, hence only these sequences were compared with our results. All the US sequences (GenBank accession nos GQ478373, GQ478377 and GQ478378), two from Valencia, Spain (FM958429 and FM958431) and the sequence from Italy (AJ586620) matched with htB, while the remaining two sequences (FM958428 and FM958430), both from Valencia, Spain, were identical to htA.

The 23S rRNA region of the contents of ten oesophageal bulbs was also tested. These flies were chosen from different populations (locations 2, 3, 6, 10, 12, 13, 17, 20, 22 and 24). A $761 \mathrm{bp}$ fragment was obtained from DNA amplification and sequencing with the universal bacterial primers (GenBank accession no. HQ667590). Upon alignment of these sequences, no nucleotide differences were observed between them. 16S rRNA gene sequencing of the same samples showed that six of them corresponded to htA and four of them corresponded to htB.

In order to check for the presence of both bacterial haplotypes in a single oesophageal bulb, the contents of eight $B$. oleae bulbs were cloned. Flies whose oesophageal bulbs were cloned were chosen mainly from populations that exhibited both bacterial haplotypes (locations 3, 5, 6, 9, 10, 16, 17 and 24, Table 1). Seven to 12 amplicons for each individual were sequenced or analysed with a restriction enzyme (ApaI). The results confirmed the presence of a unique ' $\mathrm{Ca}$. E. dacicola' haplotype in every olive fly oesophageal bulb, suggesting that htA and htB do not appear to coexist inside the same olive fly. Intermediate haplotypes between $h t A$ and $h t B$ were never found, thus implying an ancient separation of the two bacterial variants which probably originated after a prolonged period of isolation in different geographical areas. This isolation could correspond with the Pleistocenic fragmentation of different glacial refugia of the oleaster and therefore of olive fly populations (Nardi et al., 2010).

\section{‘Ca. E. dacicola' haplotype distribution}

Both htA and htB were present at different rate frequencies in all the peninsular populations, with the exception of location 4 (Table 1). Surprisingly, the olive fly populations of the two main Italian islands (Sicily and Sardinia) harboured a single symbiont haplotype: in Sardinia only htA was found, while htB was the only one recorded in Sicily. The geographical distribution of the two ' $\mathrm{Ca}$. E. dacicola' haplotypes is shown in Fig. 1. Geographical isolation could be the main explanation for this evident homogeneous distribution within the islands, as opposed to the haplotype mix observed in the peninsular populations. However, it is unlikely that accidental introduction of olive flies carrying the other symbiont haplotype to the islands has never happened, especially for a species such as B. oleae that is tightly connected with commercial cultivation and humanmediated exchanges.

The presence of population differentiation was confirmed by the tests of population differentiation $(P<0.001)$. When analysing the ' $\mathrm{Ca}$. E. dacicola' haplotype distribution among the 26 Italian olive fly populations by AMOVA, a clear geographical pattern did not appear. AMOVA was performed to analyse the origin of molecular variability in the different hierarchical levels and groups (Table 2). In the first analysis, all 26 populations analysed were considered to form a single group. In this case, AMOVA showed that about $39 \%$ of the variation was explained by differences among populations, although the highest variation occurred within the populations themselves $(60.83 \%)$. When only the peninsular populations were considered, the percentage of variance among the populations decreased to $26.25 \%$. In the successive AMOVA tests, the populations were grouped according to the Italian phytoclimatic zones proposed by Pavari (1916) or according to the presence of geographical isolation. A variance value of $38 \%$ was observed when considering the sea as a geographical barrier and thus combining the populations into three groups (peninsular populations vs. Sicily populations vs. Sardinia populations) (Table 2). Moreover, in order to test the additional influence of the orographic barrier of the Apennine mountain range, the populations were clustered into eight groups: north-east vs. north-west vs. central-west vs. central-east vs. south-west vs. south-east vs. Sicily island vs. Sardinia island (Table 2). This grouping explained a lower, but significant, proportion of variation $(34.53 \%)$, whereas it decreased $(19.42 \%)$ upon removing the two island groups (Table 2). Finally, the populations belonging to the phytoclimatic subzones of the warm Lauretum (supposedly the refugial areas of olive tree during cold periods) were grouped into four clusters that currently appear geographically isolated from each other (Liguria region vs. south Italy vs. Sicily island vs. Sardinia island). In this case, the AMOVA test showed a very high and significant percentage of variation $(51.15 \%)$ (Table 2$)$.

According to the Mantel test based on 26 populations, the genetic and geographical distances were significantly correlated ( $r=0.13, P=0.026)$. If the peninsular populations were split into two groups, separated by the orographic barrier of the Apennine mountains, the Mantel test revealed evidence for isolation by distance when considering the olive fly populations located along the Tyrrhenian coast (locations $6,7,8,9,10,13,14,16$ and 17) $(r=0.35, P=0.03)$, showing an increasing proportion of htB going south, but this became non-significant for locations close to the Adriatic coast (locations 11, 12, 18, 19 and 20) $(r=-0.18, P=0.61)$.

In order to assess variations in the distribution of the two haplotypes over time, two olive fly populations, each composed of both ' $\mathrm{Ca}$. E. dacicola' haplotypes, were monitored for three consecutive years (locality 5 from 2007 to 2009 
Table 2. AMOVA of the symbiont ' $\mathrm{Ca}$. E. dacicola' based on $16 \mathrm{~S}$ rRNA gene sequence data among populations of Bactrocera oleae divided according to the phylogeographic hypotheses discussed in the text

\begin{tabular}{|c|c|c|c|c|c|}
\hline Structure & Source of variation & d.f. & Variance $(\%)$ & Fixation indices & $P$ value \\
\hline \multirow[t]{2}{*}{ All populations } & Among populations & 25 & 39.17 & $\mathrm{~F}_{\mathrm{ST}}=0.39168$ & $<0.001$ \\
\hline & Within populations & 285 & 60.83 & & \\
\hline \multirow[t]{2}{*}{ Only peninsular populations } & Among populations & 19 & 26.25 & $\mathrm{~F}_{\mathrm{ST}}=0.26251$ & $<0.001$ \\
\hline & Within populations & 238 & 73.75 & & \\
\hline \multirow[t]{3}{*}{ Grouping by geographical region $\mathrm{I}^{*}$} & Among groups & 2 & 38.01 & $\mathrm{~F}_{\mathrm{CT}}=0.38011$ & $<0.001$ \\
\hline & Among populations within groups & 23 & 16.98 & $\mathrm{~F}_{\mathrm{SC}}=0.27397$ & $<0.001$ \\
\hline & Within populations & 285 & 45.01 & $\mathrm{~F}_{\mathrm{ST}}=0.54994$ & $<0.001$ \\
\hline \multirow[t]{3}{*}{ Grouping by geographical region II $\dagger$} & Among groups & 7 & 34.53 & $\mathrm{~F}_{\mathrm{CT}}=0.34529$ & $<0.001$ \\
\hline & Among populations within groups & 18 & 6.86 & $\mathrm{~F}_{\mathrm{SC}}=0.10484$ & $<0.001$ \\
\hline & Within populations & 285 & 58.61 & $\mathrm{~F}_{\mathrm{ST}}=0.41393$ & $<0.001$ \\
\hline \multirow[t]{3}{*}{ Grouping by geographical region III $\ddagger$} & Among groups & 5 & 19.42 & $\mathrm{~F}_{\mathrm{CT}}=0.19417$ & $<0.05$ \\
\hline & Among populations within groups & 14 & 8.89 & $\mathrm{~F}_{\mathrm{SC}}=0.11035$ & $<0.01$ \\
\hline & Within populations & 238 & 71.69 & $\mathrm{~F}_{\mathrm{ST}}=0.28309$ & $<0.001$ \\
\hline \multirow[t]{3}{*}{ Grouping by wild olive areas $§$} & Among groups & 3 & 51.15 & $\mathrm{~F}_{\mathrm{CT}}=0.51155$ & $<0.01$ \\
\hline & Among populations within groups & 11 & 12.61 & $\mathrm{~F}_{\mathrm{SC}}=0.25820$ & $<0.01$ \\
\hline & Within populations & 165 & 36.23 & $\mathrm{~F}_{\mathrm{ST}}=0.63767$ & $<0.001$ \\
\hline
\end{tabular}

${ }^{*}$ Group 1, peninsular (locations 1-20); group 2, Sicily (locations 21-23); group 3, Sardinia (locations 24-26).

†Group 1, north-east (locations 1-5); group 2, north-west (locality 6); group 3, central-west (locations 7-10); group 4, central-east (locations 11-12); group 5, south-west (locations 13-17); group 6, south-east (locations 18-20); group 7, Sicily (locations 21-23); group 8, Sardinia (locations 24-26).

‡Group 1, north-east (locations 1-5); group 2, north-west (locality 6); group 3, central-west (locations 7-10); group 4, central-east (locations 11-12); group 5, south-west (locations 13-17); group 6, south-east (locations 18-20).

§Group 1, Liguria region (locality 6); group 2, South (locations 13-20); group 3, Sicily (locations 21-23); group 4, Sardinia (locations 24-26).

and locality 6 from 2006 to 2008) (Table 1). The proportions of the two bacterial haplotypes in each population appeared not to be random as Fisher's exact test showed no significant differences in the htA-htB distributions over the years for both populations (locality 5, Fisher's exact test, d.f. $=2, P=0.56$; locality 6 , Fisher's exact test, d.f. $=2, P=0.98)$. This result suggested that the distribution of the two haplotypes seemed to be constant over time and was specific to the population.

\section{Matching the extent of symbiont and host haplotypes}

A total of 776 bases corresponding to part of the NADH dehydrogenase subunit 1 , the leucine tRNA and the $16 \mathrm{~S}$ rRNA mitochondrial region, was sequenced for 80 olive flies representing 15 populations in Italy (Table 1). DNA sequences were aligned to identify polymorphisms. A total of 16 variant sequence forms were identified (no gaps were found) and were given the haplotype designations h1 to h16. These are shown in Table 1, which also provides details of their distribution by locality. The most common and widespread haplotypes (h1 and h2) were shared by 12 and 11 populations, respectively. Seven haplotypes were unique. Each of the Italian olive fly populations analysed harboured 3.2 haplotypes on average. The sequences were deposited in GenBank under accession nos HQ667572 to HQ667587, inclusive. A network of the haplotypes was constructed (Fig. 2) using the TCS program. The analysis showed that 15 of the 16 haplotypes identified were directly connected and that only two haplotypes were missing (Fig. 2). NCPA performed with ANeCA showed that the null hypothesis of no association between the network structure and geography could not be rejected.

The overlay of the two ' $C a$. E. dacicola' haplotypes over the host mtDNA data did not show any evident association (Fig. 2). In all, the interior haplotypes (h1, h2, h3 and h5) tended to be older and more frequent than the tip haplotypes (Posada et al., 2006), both 'Ca. E. dacicola' lineages were present and their proportions did not differ significantly (Fisher's exact test, d.f. $=3, P=0.577$ ). The external mitochondrial haplotypes were not considered in this analysis because they are rare and thus strongly correlated with either one of the two ' $\mathrm{Ca}$. E. dacicola' haplotypes. The lack of an association between the symbiont and host lineages could be at least partly explained assuming the horizontal transfer of the symbiont. Even though Estes et al. (2009) have recently hypothesized an intracellular existence for ' $\mathrm{Ca}$. E. dacicola' at the larval stage, the olive fly symbiont can, at present, according to Petri (1909), be considered to be extracellular. The extracellular condition offers more potential opportunity for contacts compared with the lifestyle of endocellular symbionts. Moreover, the olive fly lifestyle, especially during the larval stage, offers opportunities for symbiont loss and reacquisition to occur, 


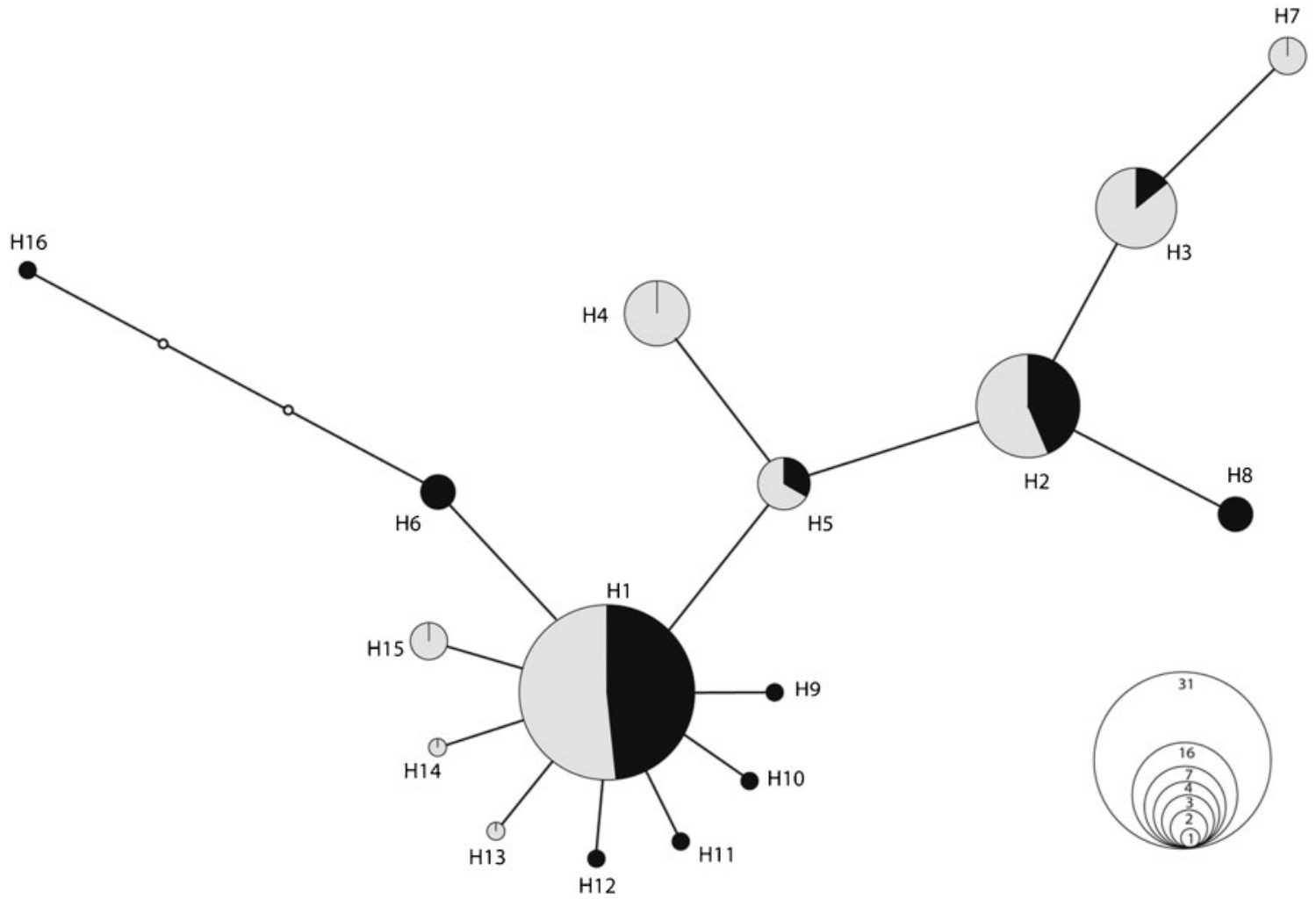

Fig. 2. Haplotype network of Bactrocera oleae realized by TCS 1.21 (Clement et al., 2000). Each haplotype is represented by a circle, with the area of the circle proportional to its frequency. The two tiny empty circles represent intermediate missing haplotypes. The proportion of the 'Ca. E. dacicola' lineage inside each circle is reported: haplotype A (black) and haplotype B (grey).

making it possible for the haplotype of ' $\mathrm{Ca}$. E. dacicola' to be replaced.

Like the majority of the fruit flies, B. oleae is tightly associated with its host plant and it spends its larval life feeding on the olive fruit pulp (Mazzon et al., 2010). It is common to observe the presence of more than one larva inside the same olive; this could offer the opportunity for possible replacement by a different haplotype of ' $\mathrm{Ca}$. E. dacicola', bypassing the model of strict vertical transmission. In such a scenario, the co-existence of both ' $\mathrm{Ca}$. E. dacicola' lineages inside the same insect host could be postulated, but in our analysis, even though it was carried out solely on adults, this has never been observed (as confirmed by cloning). Therefore, the combined occurrence of both of the ' $\mathrm{Ca}$. E. dacicola' variants in a single fly seems to be extremely rare or not possible at all due to an unknown intimate mechanism that may occur at the larval stage.

There are no clear indications about the colonization history of the olive fly and its geographical origin as they have been obscured by the long history of olive cultivation in the Mediterranean area (Daane \& Johnson, 2010), but there are data about its African origin (Nardi et al., 2005, 2010; White, 2006). We think that this report could represent the first standpoint in the understanding of the genetic variability of the olive fly in relation to that of its symbiont. Further and more comprehensive studies could address the situation that occurs over the entire colonization area of $B$. oleae by extending the research over the whole Mediterranean basin. This line of research, besides being a useful tool to fill in the details of the colonization route of the olive fly, could be a model for many investigations studying the evolutionary interdependency between insects and their associated bacteria.

\section{ACKNOWLEDGEMENTS}

We thank A. Bozzolo, V. Caleca, S. Deliperi, C. Duso, M. Faccoli, D. Fornasiero, G. Frigimelica, M. Marzaro, B. Massa, N. Mori, M. E. Noce, G. Pellizzari, E. Petrucco Toffolo, C. Rapisarda, V. Vacante, C. Villari, L. Vivan, D. Zovi for their help in collecting samples. This work is supported in part by the Italian Ministry of University (MIUR) under a Program for the Development of Research of National Interest (PRIN Grant No. 2008BPLF7Y).

\section{REFERENCES}

Behar, A., Ben-Yosef, M., Lauzon, C. R., Yuval, B. \& Jurkevich, E. (2009). Structure and function of the bacterial community associated with the Mediterranean fruit fly. In Insect Symbiosis, vol. 3, 
pp. 251-271. Edited by K. Bourtzis \& T. Miller. Boca Raton: CRC Press.

Ben-Yosef, M., Aharon, Y., Jurkevitch, E. \& Yuval, B. (2010). Give us the tools and we will do the job: symbiotic bacteria affect olive fly fitness in a diet-dependent fashion. Proc Biol Sci 277, 1545-1552.

Blando, S. \& Mineo, G. (2006). Generazioni primaverili della mosca delle olive sull'Olivastro (Olea europaea var. Sylvestris brot.) in Sicilia. Boll Zool Agra Bachic Ser 38, 173-178 (in Italian).

Breton, C., Tersac, M. \& Bervillé, A. (2006). Genetic diversity and gene flow between the wild olive (oleaster, Olea europaea L.) and the olive: several Plio-Pleistocene refuge zones in the Mediterranean basin suggested by simple sequence repeats analysis. J Biogeogr 33, 1916-1928.

Capuzzo, C., Firrao, G., Mazzon, L., Squartini, A. \& Girolami, V. (2005). 'Candidatus Erwinia dacicola', a coevolved symbiotic bacterium of the olive fly Bactrocera oleae (Gmelin). Int J Syst Evol Microbiol 55, 16411647.

Carrión, Y., Ntinou, M. \& Badal, E. (2010). Olea europaea L. in the North Mediterranean Basin during the Pleniglacial and the EarlyMiddle Holocene. Quat Sci Rev 29, 952-968.

Clement, M., Posada, D. \& Crandall, K. A. (2000). TCS: a computer program to estimate gene genealogies. Mol Ecol 9, 1657-1659.

Daane, K. M. \& Johnson, M. W. (2010). Olive fruit fly: managing an ancient pest in modern times. Annu Rev Entomol 55, 151-169.

Estes, A. M., Hearn, D. J., Bronstein, J. L. \& Pierson, E. A. (2009). The olive fly endosymbiont, "Candidatus Erwinia dacicola", switches from an intracellular existence to an extracellular existence during host insect development. Appl Environ Microbiol 75, 7097-7106.

Excoffier, L., Laval, G. \& Schneider, S. (2007). Arlequin (version 3.0): an integrated software package for population genetics data analysis. Evol Bioinform Online 1, 47-50.

Girolami, V. (1973). Reperti morfo-istologici sulle batterio simbiosi del Dacus oleae Gmelin e di altri ditteri tripetidi, in natura e negli allevamenti su substrati artificiali. Redia 54, 269-294 (in Italian).

Girolami, V. \& Cavalloro, R. (1972). Aspetti della simbiosi batterica di Dacus oleae (Gmelin) in natura e negli allevamenti di laboratorio. Ann Soc Entomol Fr 8, 561-571 (in Italian).

Hagen, K. S. (1966). Dependence of the olive fly, Dacus oleae, larvae on symbiosis with Pseudomonas savastanoi for the utilization of olive. Nature 209, 423-424.

Hunt, D. E., Klepac-Ceraj, V., Acinas, S. G., Gautier, C., Bertilsson, S. \& Polz, M. F. (2006). Evaluation of $23 \mathrm{~S}$ rRNA PCR primers for use in phylogenetic studies of bacterial diversity. Appl Environ Microbiol 72, 2221-2225.

Kounatidis, I., Crotti, E., Sapountzis, P., Sacchi, L., Rizzi, A., Chouaia, B., Bandi, C., Alma, A., Daffonchio, D. \& other authors (2009). Acetobacter tropicalis is a major symbiont of the olive fruit fly (Bactrocera oleae). Appl Environ Microbiol 75, 3281-3288.

Mazzon, L., Piscedda, A., Simonato, M., Martinez-Sañudo, I., Squartini, A. \& Girolami, V. (2008). Presence of specific symbiotic bacteria in flies of the subfamily Tephritinae (Diptera Tephritidae) and their phylogenetic relationships: proposal of 'Candidatus Stammerula tephritidis'. Int J Syst Evol Microbiol 58, 1277-1287.

Mazzon, L., Martinez-Sañudo, I., Simonato, M., Squartini, A., Savio, C. \& Girolami, V. (2010). Phylogenetic relationships between flies of the Tephritinae subfamily (Diptera, Tephritidae) and their symbiotic bacteria. Mol Phylogenet Evol 56, 312-326.

Nardi, F., Carapelli, A., Dallai, R., Roderick, G. K. \& Frati, F. (2005). Population structure and colonization history of the olive fly, Bactrocera oleae (Diptera, Tephritidae). Mol Ecol 14, 2729-2738.

Nardi, F., Carapelli, A., Boore, J. L., Roderick, G. K., Dallai, R. \& Frati, F. (2010). Domestication of olive fly through a multi-regional host shift to cultivated olives: comparative dating using complete mitochondrial genomes. Mol Phylogenet Evol 57, 678-686.

Osborn, A. M., Moore, E. R. B. \& Timmis, K. N. (2000). An evaluation of terminal-restriction fragment length polymorphism (T-RFLP) analysis for the study of microbial community structure and dynamics. Environ Microbiol 2, 39-50.

Palmano, S., Firrao, G. \& Locci, R. (2000). Sequence analysis of domains III and IV of the 23S rRNA gene of verticillate streptomycetes. Int J Syst Evol Microbiol 50, 1187-1191.

Panchal, M. (2007). The automation of nested clade phylogeographic analysis. Bioinformatics 23, 509-510.

Pavari, A. (1916). Studio preliminare sulla coltura delle specie forestali esotiche in Italia. Ann R Ist Sup For Naz I, 159-379 (in Italian).

Petri, L. (1909). Ricerche sopra i batteri intestinali della mosca olearia. Roma: Memorie della Regia Stazione di Patologia Vegetale di Roma.

Posada, D., Crandall, K. A. \& Templeton, A. R. (2000). GeoDis: a program for the cladistic nested analysis of the geographical distribution of genetic haplotypes. Mol Ecol 9, 487-488.

Posada, D., Crandall, K. A. \& Templeton, A. R. (2006). Nested Clade Analysis statistics. Mol Ecol Notes 6, 590-593.

Rice, R. E. (1999). Olive fruit fly, Bactrocera (Dacus) oleae. UC Plant Prot. Q. 9, 2.

Rousset, F. (1997). Genetic differentiation and estimation of gene flow from F-statistics under isolation by distance. Genetics 145, 12191228.

Sacchetti, P., Granchietti, A., Landini, S., Viti, C., Giovannetti, L. \& Belcari, A. (2008). Relationships between the olive fly and bacteria. J Appl Entomol 132, 682-689.

Silva, F. J., Moret, A., Neef, A. \& Belda, E. (2008). Bacterial microbiota associated with a Bactrocera oleae population from eastern Spain. In First Meeting of TEAM, Palma de Mallorca 7-8th April 2008, abstract book, vol. 15. Edited by M. A. Miranda-Chueca. Mallorca: Universitat de les Illes Balears.

Simon, C., Frati, F., Beckenbach, A., Crespi, B., Liu, H. \& Flook, P. (1994). Evolution, weighting, and phylogenetic utility of mitochondrial gene sequences and a compilation of conserved polymerase chain reaction primers. Ann Entomol Soc Am 87, 651-701.

Simon, C., Buckley, T. R., Frati, F., Stewart, J. B. \& Beckenbach, A. T. (2006). Incorporating molecular evolution into phylogenetic analysis, and a new compilation of conserved polymerase chain reaction primers for animal mitochondrial DNA. Annu Rev Ecol Evol Syst 37, 545-579.

Tamura, K., Dudley, J., Nei, M. \& Kumar, S. (2007). MEGA4: Molecular evolutionary genetics analysis (MEGA) software version 4.0. Mol Biol Evol 24, 1596-1599.

Templeton, A. R., Crandall, K. A. \& Sing, C. F. (1992). A cladistic analysis of phenotypic associations with haplotypes inferred from restriction endonuclease mapping and DNA sequence data. III. Cladogram estimation. Genetics 132, 619-633.

Templeton, A. R., Routman, E. \& Phillips, C. A. (1995). Separating population structure from population history: a cladistic analysis of the geographical distribution of mitochondrial DNA haplotypes in the tiger salamander, Ambystoma tigrinum. Genetics 140, 767-782.

Tzanakakis, M. E. (2006). Insects and Mites Feeding on Olive: Distribution, Importance, Habits, Seasonal Development and Dormancy. Leiden: Brill Acad. Publ.

Weisburg, W. G., Barns, S. M., Pelletier, D. A. \& Lane, D. J. (1991). 16 S ribosomal DNA amplification for phylogenetic study. J Bacteriol 173, 697-703.

White, I. M. (2006). Taxonomy of the Dacina (Diptera: Tephritidae) of Africa and the Middle East. Afr Entomol Mem 2, 1-156. 